\title{
Anna Wildowicz- Wyzwania polityki fiskalnej -Szumarska dla państw Unii Europejskiej w dobie pandemii COVID-19
}

Fiscal policy challenges for the European Union member states in times of COVID-19

The aim of the article is to explore the size and the structure of fiscal packages, implemented in response to the crisis caused by COVID-19, from the point of view of their impact on the security and stability of public finance. The first section provides an overview of the economic theory on the role of fiscal policy, including the causes of fiscal intervention. Next, difficulties in conducting fiscal policy under the conditions of pandemic are presented. In addition, fiscal instruments and their size are analysed in the context of their influence on budget results. In conclusion, it is claimed that fiscal packages should be temporary and targeted in order not to create a permanent burden on public finance, ensuring budget neutrality in the medium term. The empirical analysis expands the current knowledge on potential effects of fiscal policy implemented under the crisis conditions and low interest rates, when macroeconomic stabilisation can only be ensured through fiscal policy instruments, despite the accompanying fiscal costs related to the increase in public debt.

\begin{tabular}{r|l}
\hline DOI & https://doi.org/10.31268/StudiaBAS.2021.29 \\
\hline Słowa kluczowe & polityka fiskalna, instrumenty fiskalne, równowaga budżetowa \\
\hline Keywords & fiscal policy, fiscal instruments, budget balance \\
\hline O autorce & $\begin{array}{l}\text { doktor nauk ekonomicznych, Katedra Finansów, Uniwersytet } \\
\text { W Białymstoku } \cdot \square \text { a.wildowicz@uwb.edu.pl } \\
\text { ORCID 0000-0003-1871-5621 }\end{array}$ \\
\hline
\end{tabular}

(c) (1)

Artykuł został udostępniony na licencji Creative Commons - Uznanie Autorstwa 3.0 Polska (CC BY 3.0 PL).

\section{Wstęp}

Pandemia koronawirusa SARS-CoV-2 wywołała kryzys zdrowotny i gospodarczy o nieznanych dotychczas rozmiarach i na skalę globalną. W związku z tym rządy większości państw ponownie zostały zmuszone nie tylko do użycia tradycyjnych keynesowskich metod w polityce fiskalnej, lecz także do wdrożenia wielu niestandardowych rozwiązań fiskalnych celem powstrzymania rozwoju pandemii COVID-19, utrzymania płynności finansowej przedsiębiorstw, ochrony miejsc pracy i dochodu gospodarstw domowych, zagrożonych negatywnymi skutkami wprowadzonych reżimów sanitarnych oraz zamykania poszczególnych gospodarek, regionów i branż.

Większość ekonomistów podziela przekonanie, że w sytuacji pandemii - zjawiska kompletnie nieprzewidywalnego i o ekstremalnie poważnych konsekwencjach typu black swan ${ }^{1}$ - kluczową rolę odgrywa fiskalne wsparcie kierowane do przedsiębiorstw i gospodarstw domowych, które najbardziej ucierpiały w wyniku kryzysu. Z pewnością ze względu na globalny charakter pandemii COVID-19 i jej niepożądane skutki zdrowotne, społeczne oraz ekonomiczne są potrzebne

Zjawisko black swan, czyli nieprzewidywalnego, wysoce nieprawdopodobnego zdarzenia o ogromnym znaczeniu, zostało opisane w: N.N. Taleb, "Ihe Black Swan: The Impact of Highly Improbable”, Random House, New York 2007. 
nowe i bezprecedensowe rozwiązania fiskalne. Wątpliwości mogą jednak wzbudzać zarówno wielkość pakietów fiskalnych, jak i zasadność wdrażania konkretnych instrumentów.

Powyższa konstatacja skłania do sformułowania hipotezy badawczej, zgodnie z którą jednym z warunków przezwyciężenia kryzysu zdrowotnego i ekonomicznego spowodowanego pandemią COVID-19 jest implementacja odpowiedzialnej i skoordynowanej z innymi działaniami rządzących polityki fiskalnej, przy jednoczesnym zachowaniu zasady bezpieczeństwa i równowagi w finansach publicznych w średnim okresie.

Artykuł ma na celu zbadanie wielkości i struktury pakietów fiskalnych wdrożonych w odpowiedzi na kryzys wywołany pandemią COVID-19 w państwach Unii Europejskiej (UE) w kontekście ich wpływu na stabilność sektora finansów publicznych. Realizacja celu badawczego wymagała przeglądu teorii ekonomii poświęconej roli polityki fiskalnej oraz przesłankom interwencji fiskalnej. Następnie przedstawiono trudności w prowadzeniu polityki fiskalnej w dobie pandemii, a także przeanalizowano wielkość i konstrukcję instrumentów fiskalnych wraz z ich skutkami fiskalnymi. W ramach analizy empirycznej wskazano m.in. na ograniczenia budżetowe oraz niepewność związaną z pandemią, które rzutują na ostateczny kształt polityki fiskalnej.

\section{Spór o politykę fiskalną z perspektywy teorii ekonomii}

Kluczową rolę w rozwoju teorii polityki fiskalnej odegrał brytyjski ekonomista J.M. Keynes, który w okresie wielkiego kryzysu lat 30. XX w. opublikował dzieło pt. Ogólna teoria zatrudnienia, procentu i pieniqdza ${ }^{2}$. Ekonomia keynesowska na długo zdominowała teorie ekonomiczne i była z powodzeniem wykorzystywana w polityce gospodarczej wielu powojennych państw Europy Zachodniej i Stanów Zjednoczonych do lat 70. XX w.

Zgodnie z keynesowską teorią nadrzędnym zadaniem polityki fiskalnej - a także polityki pieniężnej - jest stabilizacja makroekonomiczna. Generalnie antycykliczna polityka fiskalna powinna działać w sposób przeciwny do kierunku cyklu koniunkturalnego. Oznacza to, że w przypadku recesji zaleca się wzrost wydatków rządowych lub obniżanie podatków, ponieważ takie działania mają pozytywny wpływ na zagregowane wydatki konsumpcyjne, a w konsekwencji zwiększają łączny popyt, dochody realne i poziom zatrudnienia ${ }^{3}$. W sytuacji przegrzania koniunktury i groźby inflacji należy zaś dążyć do ograniczenia wydatków rządowych i wzrostu podatków. Rozmiary interwencji fiskalnej są uzależnione od rozmiarów recesji, a na jej efektywność wpływa wartość mnożnika fiskalnego rozumiana jako skumulowany wynik produkcji wywołany wzrostem wydatków rządowych, które mają łagodzić skutki kryzysu ${ }^{4}$. Warto podkreślić, że zdaniem Keynesa w warunkach kryzysu gospodarczego zmiany realnej produkcji przekładają się na wzmocnienie efektów mnożnikowych, a to skutkuje jeszcze większym wzrostem dochodu narodowego. Pomimo że ekspansywna polityka fiskalna prowadzi do deficytu budżetowego

2 J.M. Keynes, Ogólna teoria zatrudnienia, procentu i pieniqqdza, Wydawnictwo Naukowe PWN, Warszawa 2003.

3 Ö.H. Birol, A.H. Gencer, The Keynesian System: Fiscal and Monetary Policy Guidelines, "GSTF International Journal of Business Review" 2014, t. 3, nr 3, s. 106-119.

4 S. Bose, N.R. Bhanumurthy, Fiscal Multipliers for India, http://www.nipfp.org.in/media/medialibrary/2013/09/ WP_2013_125.pdf [dostęp: 18 sierpnia 2021 r.]. 
i długu publicznego, nie jest zjawiskiem negatywnym, o ile mamy bezrobocie w gospodarce, a oszczędności przewyższają wartość inwestycji.

Całkowicie odmienne stanowisko w kwestii polityki fiskalnej reprezentują twórca monetaryzmu M. Friedman i jego zwolennicy. Według nich gospodarka jest z natury stabilna, a jej potencjalną chwiejność przypisuje się destabilizującym wahaniom podaży pieniądza, które zazwyczaj stanowią efekt interwencji władz monetarnych. Innymi słowy, najczęściej źródłem kryzysów jest spadek ilości pieniądza i liczby udzielanych kredytów, podczas gdy okresy boomu i inflacji wiążą się z nadmiernym wzrostem podaży pieniądza. Z tej właśnie przyczyny monetaryści uznają, że jedynie polityka pieniężna powinna być narzędziem wspomagającym gospodarkę ze względu na naturalne zdolności tej ostatniej do samoregulacji. Natomiast jakiekolwiek próby łagodzenia szoków popytowych przez antycykliczną politykę fiskalną są nieskuteczne z co najmniej kilku powodów ${ }^{5}$. Po pierwsze, gospodarstwa domowe mogą nie reagować na krótkookresowe zmiany dochodów. Aby utrzymać dotychczasowy poziom konsumpcji, wykorzystują bowiem posiadane oszczędności lub zaciągają pożyczki. W rezultacie celem jednorazowych transferów z budżetu państwa i obniżek podatków nie jest zwiększenie konsumpcji, lecz skłonienie gospodarstw domowych do gromadzenia oszczędności. Skłonność do odkładania pieniędzy rośnie prawdopodobnie wówczas, gdy gospodarstwa domowe spodziewają się wzrostu podatków w przyszłości, niezbędnych do spłaty dodatkowego długu publicznego zaciągniętego przez rząd w celu sfinansowania wydatków publicznych. Opisane zjawisko określa się mianem ekwiwalencji ricardiańskiej. Po drugie, inwestycje prywatne mogą zostać „wyparte” przez inwestycje publiczne. Wzrost potrzeb pożyczkowych rządu - niezbędnych do sfinansowania wprowadzonych bodźców fiskalnych może prowadzić do wzrostu stóp procentowych, a to przekłada się na niższy poziom inwestycji w sektorze przedsiębiorstw. Ponadto należy pamiętać o tym, że przy niskim zaufaniu do polityki fiskalnej rządu wzrasta również oprocentowanie obligacji skarbowych, przez co rosną koszty finansowania zewnętrznego w całej gospodarce. Po trzecie, pojawiają się ograniczenia po stronie podaży, które stanowią barierę uniemożliwiającą dalszy wzrost produkcji w odpowiedzi na wzrost zagregowanego popytu stworzonego przez bodźce fiskalne. Zazwyczaj skutkuje to wyższym poziomem inflacji, wzrostem stóp procentowych (a w efekcie wypieraniem inwestycji prywatnych) lub wzrostem importu, przez co prowadzi do ostatecznego stłumienia wpływu impulsu fiskalnego.

Przedstawione argumenty wykorzystali zwolennicy teorii niekeynesowskich efektów polityki fiskalnej w latach 90. XX w. ${ }^{6} \mathrm{~W}$ świetle założeń tej koncepcji należy dążyć do ograniczania deficytu budżetowego, gdyż dzięki temu można zapewnić zarówno poprawę stanu finansów publicznych (spadek kosztów obsługi długu), jak i wzrost gospodarki realnej w średnim i długim okresie. Stąd adepci tej teorii zalecają politykę zaciskania pasa (austerity), polegającą na cięciu wydatków publicznych i wzroście podatków celem przywrócenia równowagi w sektorze finansów publicznych.

5 M. Friedman, W. Heller, Monetary vs. Fiscal Policy, W.W. Norton \& Company, New York 1969.

6 A. Alesina, R. Perotti, Fiscal Adjustments in OECD Countries: Composition and Macroeconomic Effects, „IMF Staff Papers" 1997, t. 44, nr 2, S. 210-248; A. Afonso, Expansionary Fiscal Consolidations in Europe. New Evidence, „Working Papers Series" 2006, nr 675; C.M. Reinhart, K.S. Rogoff, Growth in a Time of Debt, "NBER Working Paper Series" 2010, nr 15 639, s. 573-578. 
Badania empiryczne pokazały, że zbyt wczesna konsolidacja fiskalna w strefie euro po $2010 \mathrm{r}$. i odejście od wdrożonych na krótko po kryzysie pakietów fiskalnych - zgodnie z zaleceniami keynesowskiej ekonomii - były błędem ${ }^{7}$. Stwierdzono, że polityka austerity w warunkach głębokiej recesji gospodarczej oraz przy zerowym poziomie rynkowych stóp procentowych doprowadziła do spotęgowania działania ujemnych keynesowskich mnożników oraz niepożądanych efektów histerezy, które odpowiadają za nieodwracalne straty potencjalnego PKB.

W podsumowaniu należy wskazać, że wyniki badań empirycznych z ostatnich lat nie pozwalają na zakwestionowanie znaczenia polityki fiskalnej dla stabilizacji makroekonomicznej, lecz wskazują, że jej skuteczność zależy od krótkookresowych mnożników fiskalnych. O sile przekształceń podstawowych wielkości makroekonomicznych (konsumpcja, inwestycje, zatrudnienie, PKB) pod wpływem zmian wielkości instrumentów polityki fiskalnej przesądza wartość mnożnika fiskalnego. Tę wartość determinują cechy gospodarki - zarówno te strukturalne, jak i koniunkturalne ${ }^{8}$. Koniunkturalne czynniki - o charakterze tymczasowym - mają wpływ na poziom mnożników, które przyjmują zdecydowanie większe wartości w okresach spowolnienia gospodarczego niż boomu na rynkach. Dodatkowo mnożniki mogą być wyższe wówczas, gdy stopy procentowe są bliskie zera i nie ma możliwości prowadzenia ekspansywnej polityki pieniężnej. Z taką sytuacją mamy do czynienia obecnie m.in. w państwach UE, co stanowi przesłankę dla interwencji fiskalnej.

\section{Trudności w realizacji polityki fiskalnej w warunkach pandemii}

Pandemia COVID-19 spowodowała, że gospodarki unijne znalazły się w głębokiej recesji. W efekcie, jak pokazują statystyki, PKB w UE-27 zmniejszył się o prawie 6\% w 2020 r. ${ }^{9}$ Wymusiło to na rządach konieczność powrotu do ekspansywnej polityki fiskalnej, a więc wykorzystania keynesowskich metod podtrzymywania koniunktury, które przy niemal zerowych stopach procentowych - ograniczających możliwość interwencji ze strony władz monetarnych - mają znaczenie priorytetowe.

Opinię o tym, że pakiety fiskalne w okresie kryzysu są niezbędne do minimalizowania strat wywołanych pandemią i szybkiego przywrócenia stabilności makroekonomicznej, podziela większość ekonomistów pomimo doskonale znanych z literatury przedmiotu słabości polityki fiskalnej. Najczęściej do mankamentów polityki fiskalnej zalicza się krótkowzroczność i opor-

7 J.B. DeLong, L.H. Summers, Fiscal Policy in a Depressed Economy, „Brookings Papers on Economic Activity" 2012, s. 233-265; A.J. Auerbach, Y. Gorodnichenko, Measuring the Output Responses to Fiscal Policy, „American Economic Journal: Economic Policy” 2012, t. 4, nr 2, s. 1-27; A.J. Auerbach, Y. Gorodnichenko, Output Spillovers from Fiscal Policy, „American Economic Review” 2013, t. 103, nr 3, s. 141-146, https://doi. org/10.1257/aer.103.3.141; T. Herndorn, M. Ash, R. Pollin, Does High Public Debt Consistently Stifle Economic Growth? A Critique of Reinhart and Rogoff, "Cambridge Journal of Economics" 2014, t. 38, nr 2, s. 257-279, https://doi.org/10.1093/cje/bet075; A. Fatás, L.H. Summers, The Permanent Effects of Fiscal Consolidation, „NBER Working Paper" 2016, nr 22 374, s. 1-34, https://doi.org/10.3386/w22374.

8 J. Herda, Pomiar mnożnika fiskalnego, „Studia i Prace WNEIZ US” 2017, nr 47/1, s. 35-45.

9 Eurostat Database, Real GDP Growth Rates - volume [TEC00115], https://ec.europa.eu/eurostat/databrowser/ view/tec00115/default/table?lang=en [dostęp: 18 sierpnia 2021 r.]. 
tunizm decydentów politycznych wprowadzających programy socjalne lub obniżki podatków z myślą o przyszłej reelekcji ${ }^{10}$. Wskazuje się także na asymetrię informacji, które posiadają rząd i elektorat, wyborcy nie są bowiem świadomi ograniczeń budżetowych, a rządzący bywają skłonni do procyklicznej polityki fiskalnej skutkującej rosnącymi deficytami ${ }^{11}$. Inna przyczyna skłonności do nadmiernych deficytów (deficit bias) wynika z problemu tzw. wspólnej puli (common-poo/). Różne grupy interesu mogą lobbować na rzecz wzrostu określonego rodzaju wydatków publicznych, ponieważ są dla nich korzystne, przy czym nie biorą one pod uwagę długoterminowych kosztów związanych z ich finansowaniem przez wszystkich podatników ${ }^{12}$. Przyczyną deficytów i procykliczności jest też niespójność w czasie polityki fiskalnej (time inconsistency). $Z$ reguły polityka fiskalna ex ante jest zgodna z interesem publicznym, lecz ex post jest zdominowana interesami wyborczymi lub regionalnymi. W praktyce przejawem niespójności czasowej polityki fiskalnej jest pokusa nadmiernego wykorzystywania deficytów fiskalnych także w okresie ożywienia gospodarczego ${ }^{13}$.

Dodatkowo warto zauważyć, że w przypadku załamania gospodarki wywołanego epidemią koronawirusa nie mamy do czynienia z typową recesją, a to przysparza kolejnych trudności związanych z realizacją polityki fiskalnej. Z teorii dotyczącej bodźców fiskalnych wynika, że podstawowym warunkiem ich skuteczności jest stosowanie zasady 3T w polityce fiskalnej. Wdrażane instrumenty fiskalne powinny być: timely (terminowe), targeted (ukierunkowane) i temporary (doraźne) ${ }^{14}$.

Zasada terminowości oznacza, że implementację dyskrecjonalnych instrumentów fiskalnych, które mają działać antycyklicznie, należy rozłożyć odpowiednio w czasie. Zgodnie z takim założeniem fiskalne wsparcie w postaci obniżenia podatków lub zwiększania wydatków jest kierowane do podmiotów w okresie spowolnienia gospodarki celem zwiększenia zagregowanego popytu i pobudzenia wzrostu gospodarczego. Natomiast wprowadzane z opóźnieniem bodźce fiskalne

10 A. Alesina, G. Tabellini, A Positive Theory of Fiscal Deficits and Government Debt, "The Review of Economic Studies" 1990, t. 57, nr 3, https://doi.org/10.2307/2298021; iidem, Why Is Fiscal Policy Often Procyclical, „NBER Working Paper Series" 2005, nr 11 600; iidem, Bureaucrats or Politicians? Part I: A Single Policy Task, "American Economic Review" 2007, t. 97, nr 1, s. 169-179; J.E. Alt, D.D. Lassen, Fiscal Transparency, Political Parties, and Debt in OECD Countries, „European Economic Review” 2006, t. 50, nr 6, s. 1403-1439, https://doi. org/10.1016/j.euroecorev.2005.04.001; L. Calmfors, S. Wren-Lewis, What Should Fiscal Councils Do?, „Economic Policy" 2011, t. 26, nr 68, s. 651-695; S. Wren-Lewis, Aggregate Fiscal Policy under the Labour Government. 1997-2010, „Oxford Review of Economic Policy” 2013, t. 29, nr 1, s. 25-46, https://doi.org/10.1093/oxrep/ grt012; R.M.W.J. Beetsma et al., Independent Fiscal Councils: Recent Trends and Performance, „IMF Working Papers" 2018, t. 18, nr 68.

11 A. Alesina, G. Tabellini, Why...; R.M.W.J. Beetsma, X. Debrun, Fiscal Councils: Rationale, and Effectiveness, „IMF Working Papers" 2016, t. 16, nr 86.

12 J. von Hagen, I. Harden, Budget Processes and Commitment to Fiscal Discipline, "European Economic Review” 1995, t. 39, nr 3-4, s. 771-779; R. Perotti, Y. Kontopoulos, Fragmented Fiscal Policy, „Journal of Public Economics" 2002, t. 86, nr 2, s. 191-222.

13 R. Hagemann, How Can Fiscal Councils Strengthen. Fiscal Performance?, "OECD Journal: Economic Studies” 2011, nr 1, s. 1-24.

14 I. Steel, T. Harris, COVID-19 Economic Recovery: Fiscal Stimulus Choices for Lower-Income Countries, Institute for Fiscal Studies, London 2020, s. 10. 
nie mogą pomóc wkraczającej w fazę ożywienia gospodarce, ponieważ groziłoby to jedynie jej przegrzaniem.

Niestety, zachowanie zasady terminowości w warunkach pandemii koronawirusa wydaje się wyjątkowo trudne ze względu na wysoki poziom niepewności, jaki epidemia generuje. Zbyt szybka implementacja bodźców fiskalnych - przy nadal stosunkowo wysokim poziomie transmisji wirusa i niskim odsetku osób zaszczepionych oraz przy powracających lockdownach (czasowym, przestrzennym lub sektorowym zamykaniu gospodarki) - może okazać się mało skuteczna. Aby można było zastosować bodźce fiskalne, liczba nowych zachorowań powinna być relatywnie niska i stabilna, a także zsynchronizowana z polityką stopniowego otwierania gospodarki i znoszenia ograniczeń z tym związanych. Dlatego harmonogram wprowadzania instrumentów fiskalnych przez władze fiskalne należy dostosować zarówno do fazy cyklu koniunkturalnego, jak i do aktualnego stanu pandemii ${ }^{15}$.

Zasada ukierunkowania w polityce fiskalnej wymusza na rządzie konieczność wyboru podmiotów gospodarczych, do których ma być skierowane wsparcie. Zamiast wprowadzania bodźców fiskalnych o charakterze ogólnym preferuje się wsparcie selektywne poszczególnych sektorów i branż o największym znaczeniu dla gospodarki. Ukierunkowane bodźce fiskalne powinny uruchomić działanie wysokich mnożników fiskalnych w krótkim okresie i oddziaływać na stronę gospodarki zarówno popytową, jak i podażową. Z tego punktu widzenia istotną rolę odgrywa wsparcie fiskalne udzielane gospodarstwom domowym o niskich dochodach oraz przedsiębiorstwom borykającym się z problemem płynności finansowej. Dzięki temu są zabezpieczone dochody osób, które mają wysoką skłonność do konsumpcji. Niespełnienie tego warunku grozi marnotrawstwem publicznych pieniędzy i pogłębieniem nierównowagi w gospodarce ${ }^{16}$.

Właściwe ukierunkowanie bodźców fiskalnych w dobie pandemii koronawirusa jest ogromnym wyzwaniem dla gospodarki globalnej cechującej się intensywnymi powiązaniami sieciowymi. Z tej przyczyny objęcie wsparciem fiskalnym podmiotów, które najbardziej ucierpiały na skutek pandemii - na przykład eksporterów i branży turystycznej - choć jest zasadne, może nie przynieść keynesowskich efektów mnożnikowych. Zjawisko to należy tłumaczyć tym, że funkcjonowanie tych branż zależy głównie od zagranicznych odbiorców, dostawców i kooperantów, a także od obowiązujących z powodu pandemii wymogów sanitarno-epidemiologicznych. W tej sytuacji zastosowanie instrumentów fiskalnych o charakterze bodźcowym może być mało skuteczne. Istnieje też przekonanie, że część wsparcia fiskalnego nie tylko ma pomóc w podtrzymaniu popytu konsumpcyjnego, który został osłabiony w wyniku kryzysu COVID-19, i inwestycyjnego w sektorach dotkniętych tym kryzysem oraz ułatwić ich szybszą adaptację, lecz także posłużyć do zainicjowania głębszych przemian strukturalnych w gospodarce.

Zgodnie z zasadą tymczasowości (doraźności) bodźce fiskalne nie mogą zwiększać przyszłych deficytów. Zastosowanie instrumentów fiskalnych ma wpłynąć wyłącznie na przyspieszenie bieżących wydatków gospodarstw domowych i przedsiębiorstw. Zaleca się więc rezygnację z bodźców stymulacyjnych i bezwzględny powrót do konsolidacji fiskalnej wraz z poprawą koniunktury

15 Ibidem, s. 10.

16 Ibidem, s. 14. 
gospodarczej. Nadmierne wydatki rządowe i zadłużenie mogą „wypierać" prywatne inwestycje i osłabiać wzrost gospodarczy, a zbyt duży dług publiczny może implikować negatywne skutki makroekonomiczne związane ze wzrostem stóp procentowych i z inflacją.

Niepewność związana z przebiegiem pandemii COVID-19 sprawia, że trudno jest precyzyjnie określić ramy czasowe, w jakich powinny obowiązywać poszczególne bodźce fiskalne. O ile obniżone stawki VAT stanowią rozwiązanie przejściowe i powinny być stosowane nie dłużej niż rok, o tyle zdecydowanie warto rozważyć przedłużenie niektórych preferencji podatkowych w postaci ulg i odliczeń w podatku dochodowym (co najmniej na okres dwóch-trzech lat). Rozwiązaniem alternatywnym - zamiast wyznaczonych ram czasowych dla bodźców fiskalnych mogą być też wskaźniki makroekonomiczne (na przykład zawieszenie bodźców, gdy tylko konsumpcja osiągnie ustalony poziom) lub wskaźniki pandemiczne (odsetek osób zaszczepionych w populacji). Jednakże również tego typu rozwiązania nie są pozbawione mankamentów. Brak konkretnych ram czasowych, w jakich obowiązywałyby bodźce fiskalne, może powstrzymywać gospodarstwa domowe przed zwiększeniem bieżącej konsumpcji, a przedsiębiorstwa - przed podejmowaniem inwestycji. Ponadto alternatywne rozwiązania - bez podania ram czasowych są zazwyczaj obarczone dużym ryzykiem, ponieważ w praktyce mogą generować większe koszty, niż pierwotnie zakładano, ze względu na wysoki stopień niepewności co do czasu osiągnięcia ustalonego poziomu wskaźników w przyszłości ${ }^{17}$.

W ramach podsumowania można wskazać, że szok gospodarczy wywołany pandemią wirusa SARS-CoV-2 znacznie się różni od poprzednich recesji. Nie zwalnia to jednak z obowiązku respektowania zasady 3T w polityce fiskalnej, ponieważ tylko dzięki niemu wprowadzane bodźce fiskalne mogą być skuteczne i wspierać osiąganie pożądanych wyników zarówno gospodarczych, jak i zdrowotnych.

\section{Rozmiary i struktura pakietów fiskalnych w państwach UE}

Państwa UE-27 uruchomiły znaczne środki w odpowiedzi na pandemię COVID-19. Przeciętna wartość pakietów fiskalnych wyniosła 4,2\% PKB w 2020 r., podczas gdy ich wartość w 2021 r. szacuje się na 2,4\% PKB ${ }^{18}$. Większość środków nadzwyczajnych (emergency measures) podjęto w celu przeciwdziałania kryzysowi zdrowotnemu i ekonomicznemu, usprawnienia funkcjonowania systemu ochrony zdrowia oraz zrekompensowania przedsiębiorstwom strat dochodów spowodowanych wybuchem pandemii. Oszacowano, że wartość kierowanych do przedsiębiorców i pracowników rekompensat w 2020 r. wyniosła 3,4\% PKB, a w 2021 r. ma stanowić $0,9 \%$. Natomiast inne instrumenty fiskalne, takie jak obniżki podatków pośrednich lub roboty publiczne, wykorzystywane do wywołania ożywienia gospodarczego osiągnęły wartość 0,8\% PKB w 2020 r. ${ }^{19}$ Należy przy tym podkreślić, że o ile ich udział w pakietach fiskalnych w 2020 r. nie przekraczał 20\%, o tyle w 2021 r. może wzrosnąć nawet do 67\%, ponieważ dopiero wówczas,

17 Ibidem, s. 17-18.

18 European Commission, Communication from the Commission to the European Parliament, the Council, and the European Central Bank on the 2021 Draft Budgetary Plans: Overall Assessment, Brussels 2020, s. 2.

19 Ibidem, s. 8. 
gdy gospodarki unijne wkroczą w fazę ożywienia, implementacja bodźców fiskalnych może przynieść pozytywne efekty keynesowskie. Z tej przyczyny państwa członkowskie w głównej mierze koncentrowały się na zapewnieniu płynności gospodarstwom domowym i w sektorze przedsiębiorstw dotkniętych lockdownami oraz zaburzeniami w łańcuchach dostaw. Stosowały środki nadzwyczajne w postaci gwarancji bankowych lub zawieszenia podatków i składek na ubezpieczenie społeczne.

Wykres 1 przedstawia rozmiary dyskrecjonalnej pomocy fiskalnej udzielonej w odpowiedzi na kryzys COVID-19 w wybranych państwach UE. Wartości zaczerpnięto z bazy danych International Monetary Fund (IMF).

\section{Wykres 1. Dyskrecjonalna reakcja fiskalna na kryzys COVID-19 w wybranych gospodarkach (w \% PKB)}

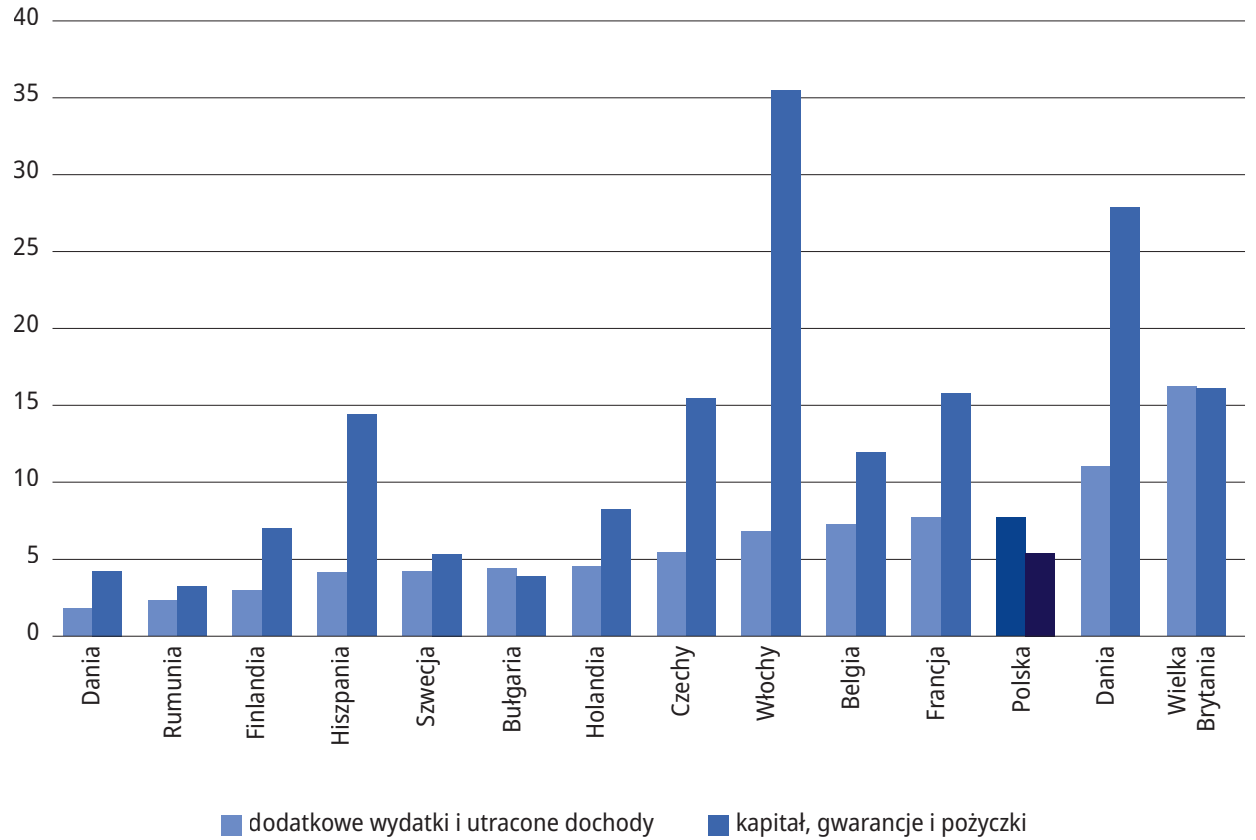

Źródło: International Monetary Fund, Fiscal Monitor Database Database of Country Fiscal Measures in Response to the COVID-19 Pandemic, 2021, https://www.imf.org/en/Topics/imf-and-covid19/Fiscal-Policies-Database-in-Response-to-COVID-19 [dostęp: 18 sierpnia 2021 r.].

Z danych IMF wynika, że dominującą formą wsparcia są gwarancje i pożyczki oraz odroczenia w płatności podatku stosowane celem utrzymania płynności sektora prywatnego. Przy tym wartość wydatków związanych z gwarancjami i pożyczkami, których udzielono w państwach strefy euro w 2020 r., szacuje się na 19\% PKB, a w państwach członkowskich UE - na 17\% PKB. Jak podano w statystykach, wartość odroczeń z tytułu płatności podatku i składek na ubezpieczenia społeczne nie przekraczała w państwach UE 1\% PKB. Państwa członkowskie 
udzieliły również gwarancji w celu wsparcia nowych instrumentów na szczeblu UE, w szczególności w ramach programu Wsparcie w Łagodzeniu Ryzyka Bezrobocia w Nagłych Wypadkach (Support to Mitigate Unemployment Risks in an Emergency, SURE) i Europejskiego Funduszu Gwarancyjnego ${ }^{20}$.

Jak wskazano w raporcie pt. Tax and Fiscal Policy in Response to the Coronavirus Crisis: Strengthening Confidence and Resilience ${ }^{21}$, silna i terminowa pomoc fiskalna w pierwszej połowie $2020 \mathrm{r}$. odegrała kluczową rolę we wspieraniu gospodarstw domowych, w zachowaniu miejsc pracy i utrzymaniu płynności finansowej przez przedsiębiorstwa. Według danych OECD większość państw UE wykorzystywała w tym celu instrumenty podatkowe, takie jak odroczenie płatności podatków PIT, CIT i składek na ubezpieczenia społeczne. Niektóre państwa UE (Węgry i Polska) zdecydowały się też na zwolnienia podatkowe oraz zwiększone rezerwy na pokrycie strat (Polska, Czechy i Słowacja). Z kolei wśród instrumentów wydatkowych dominowały: dopłaty do wynagrodzeń wypłacane pracodawcom (Irlandia, Dania, Szwecja, Austria, Polska, Litwa i Słowenia) i osobom samozatrudnionym (Francja, Niemcy, Irlandia, Dania, Włochy, Hiszpania, Grecja, Litwa i Polska), a także dofinansowanie pozapłacowych kosztów prowadzenia działalności (Włochy, Grecja, Austria i Niemcy). Ponadto bezpośrednim wsparciem objęto sektory związane z turystyką, wypoczynkiem i transportem, które najbardziej ucierpiały na skutek wybuchu pandemii (Austria, Belgia, Estonia, Węgry, Włochy, Portugalia i Szwecja) ${ }^{22}$.

Podobne instrumenty podatkowe, a więc przede wszystkim odroczenia podatkowe, zostały zastosowane głównie z myślą o gospodarstwach domowych (Austria, Belgia, Niemcy, Holandia, Hiszpania, Włochy, Irlandia, Węgry, Czechy, Łotwa i Szwecja). Zdecydowanie mniej państw (Belgia, Węgry i Irlandia) dodatkowo wprowadziło zwolnienia podatkowe lub przedłużyło terminy składania rocznych zeznań podatkowych (Belgia, Francja, Luksemburg i Słowacja). W przypadku gospodarstw domowych największe znaczenie miały przede wszystkim bezpośrednie transfery i rozszerzony dostęp do świadczeń socjalnych. Na dopłaty do wynagrodzeń pracowników zagrożonych całkowicie lub częściowo utratą zatrudnienia zdecydowały się m.in.: Belgia, Francja, Holandia, Hiszpania, Grecja, Portugalia i Estonia. Wiele państw UE równocześnie rozszerzyło dostępność lub zwiększyło kwoty zasiłków dla bezrobotnych (Niemcy, Austria, Holandia, Hiszpania, Grecja, Portugalia i Szwecja), zasiłków chorobowych (Niemcy, Szwecja, Estonia, Litwa, Słowacja, Portugalia i Irlandia) czy zasiłków z tytułu przymusowej opieki rodzicielskiej nad dziećmi w domu (Francja, Grecja, Portugalia, Litwa, Polska i Słowacja) ${ }^{23}$. Należy nadmienić, że Niemcy z dniem 1 stycznia 2021 r. zwiększyły też dochód wolny od opodatkowania. Holandia i Czechy

20 European Commission, Report on Public Finances in EMU, "Institutional Paper” 2021, nr 147, s. 18.

21 OECD, Tax and Fiscal Policy in Response to the Coronavirus Crisis: Strengthening Confidence and Resilience, Paris 2020, https://read.oecd-ilibrary.org/view/?ref=128_128575-o6raktc0aa\&title=Tax-and-Fiscal-Policy-in-Response-to-the-Coronavirus-Crisis\&_ga=2.17380987.357138348.1629207283-563058973.1620212770? [dostęp: 18 sierpnia 2021 r.].

22 OECD, Country Tax Measures During the COVID-19 Pandemic, https://www.oecd.org/tax/tax-policy/ [dostęp: 18 sierpnia 2021 r.].

23 OECD, Country... 
podwyższyły ulgę podatkową (tax credit) dla pracujących i samozatrudnionych, a Niemcy i Estonia zwiększyły odliczenia od dochodu dla rodzin z dziećmi ${ }^{24}$.

\section{Wpływ pakietów fiskalnych na nierównowagę sektora finansów publicznych w państwach członkowskich}

Pomimo podobieństw - między regionami i państwami UE - istnieją pewne różnice w wielkości pakietów fiskalnych. Wydaje się, że są one nie tylko wynikiem zróżnicowanego tempa rozprzestrzeniania się wirusa oraz odmiennych strategii walki z COVID-19. Z pewnością kształt i wielkość pakietów fiskalnych zależą od istniejących rozwiązań instytucjonalnych w modelach państwa opiekuńczego (welfare state), w tym od struktury systemu podatkowego. Szczególnie istotnym czynnikiem jest przestrzeń fiskalna, która determinuje rozmiary dyskrecjonalnej reakcji fiskalnej.

\section{Wykres 2. Saldo budżetowe w państwach UE-27 jako \% PKB*}

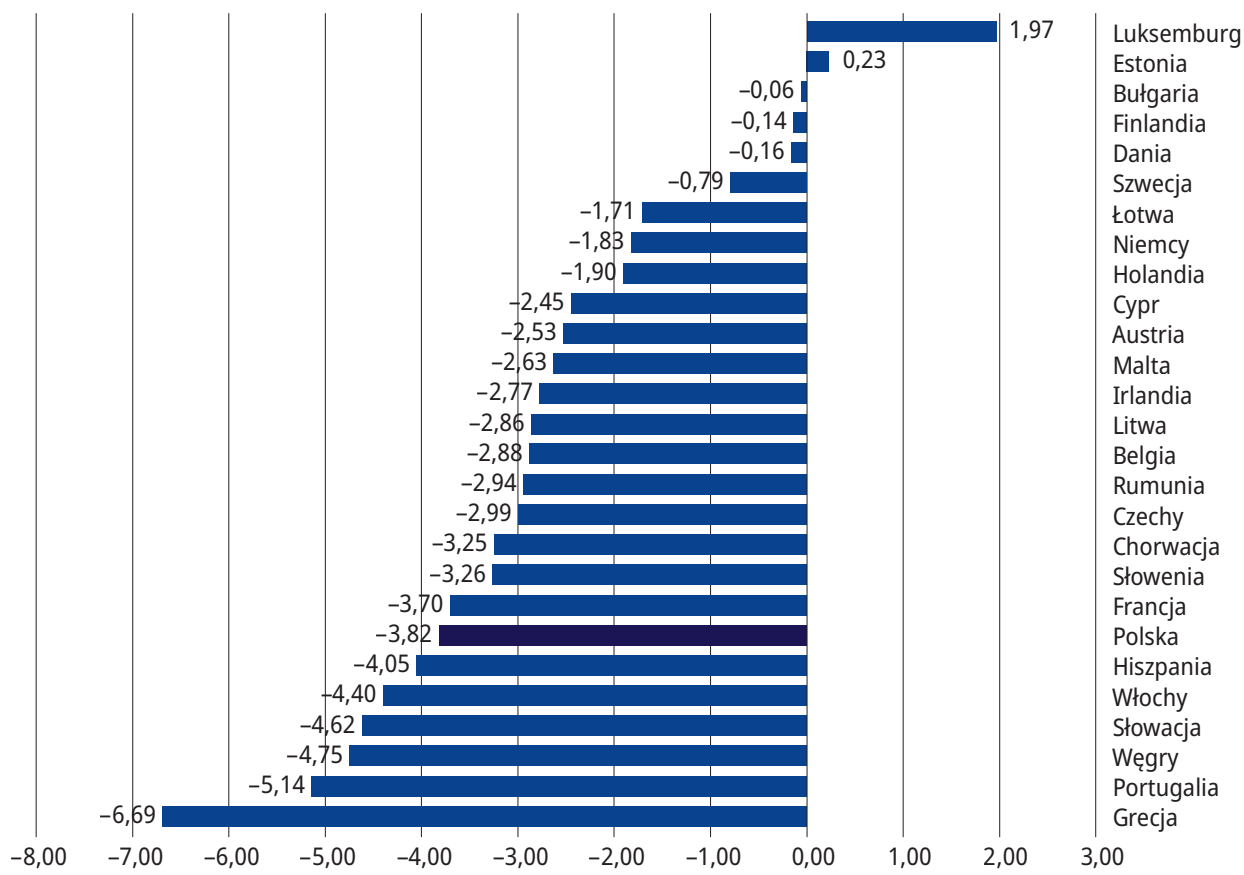

* średnia z lat 2007-2019

Źródło: opracowanie własne na podstawie danych The World Bank, A Cross-Country Database of Fiscal Space, http://www.worldbank.org/en/research/brief/fiscal-space [dostęp: 18 sierpnia 2021 r.].

24 OECD, Tax Policy Reforms 2021: Special Edition on Tax Policy during the COVID-19 Pandemic, OECD Publishing, Paris 2021, https://doi.org/10.1787/427d2616-en, s. 45-46. 
Na wykresie 2 przedstawiono przeciętne saldo budżetowe sektora finansów publicznych państw UE. Największa nierównowaga fiskalna charakteryzowała kraje śródziemnomorskie, takie jak Grecja (-6,69\% PKB), Portugalia (-5,14\%), Włochy (-4,40\%) i Hiszpania (-4,05\%). Natomiast nadwyżkę w sektorze finansów publicznych odnotowano jedynie w Luksemburgu (1,97\% PKB) i Estonii (0,23\%). Stosunkowo korzystnie na tym tle wypadły również kraje skandynawskie: Finlandia (-0,14\%), Dania (-0,16\% PKB) i Szwecja (-0,79\%).

Przeciętny poziom zadłużenia państw UE został zaprezentowany na wykresie 3. Dodatkowo uwzględniono szacunkowe dane o długu publicznym z lat 2020-2021 opublikowane w raporcie Komisji Europejskiej ${ }^{25}$.

\section{Wykres 3. Poziom długu publicznego w państwach UE-27 jako \% PKB*}

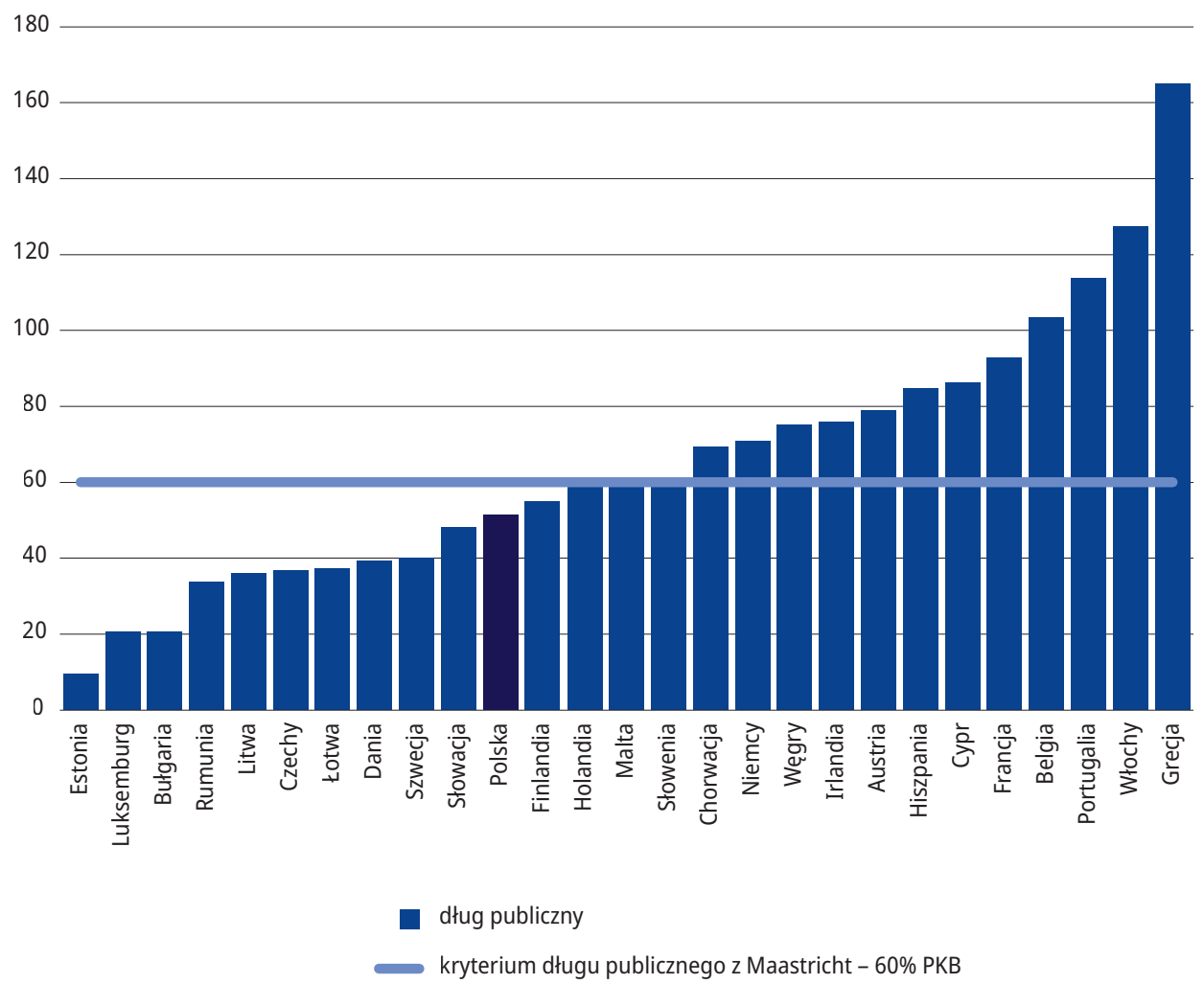

\footnotetext{
* średnia z lat 2007-2021
}

Źródło: opracowanie własne na podstawie General Government Gross Debt (EDP Concept), Consolidated Annual Data, https://ec.europa.eu/eurostat/tgm/table.do?tab=table\&init=1\&language=en\&pcode=tipsgo10\&plugin=1 [dostęp: 19 sierpnia 2021 r.] oraz European Commission, Report on Public Finances in EMU, „Institutional Paper” 2021, nr 147, s. 13. 
Największą niestabilność fiskalną - mierzoną poziomem długu publicznego - wykazują kraje śródziemnomorskie: Grecja (164,9\% PKB), Włochy (127,4\%) i Portugalia (113,6\%). Należy przy tym nadmienić, że prawie połowa spośród państw UE odznacza się brakiem stabilności fiskalnej, przez co nie spełnia podstawowego kryterium fiskalnego związanego z wysokością długu publicznego nieprzewyższającą 60\% PKB. Ponadto dług publiczny w pięciu państwach UE (Grecja, Włochy, Portugalia, Belgia i Francja) przekracza poziom 90\% PKB.

Jedną z przyczyn niestabilności sektora finansów publicznych jest kryzys COVID-19, który doprowadził do wzrostu deficytów budżetowych i długu publicznego w państwach UE-27. Tylko w strefie euro deficyt budżetowy zwiększył się z 0,6\% PKB w 2019 r. do 8,8\% w 2020 r. Deficyty budżetowe i spadek PKB przyczyniły się także do wzrostu wskaźnika zadłużenia w strefie euro z 85,9\% PKB w 2019 r. do 101,7\% w 2020 r. ${ }^{26}$ Pogorszenie sald budżetowych częściowo jest efektem działania automatycznych stabilizatorów, które mają na celu złagodzenie skutków cyklu gospodarczego. Według szacunków Europejskiego Banku Centralnego (EBC) w 2020 r. wzrost zadłużenia był w jednej trzeciej spowodowany działaniem automatycznych stabilizatorów koniunktury, w dwóch trzecich zaś wywołały go dyskrecjonalne działania fiskalne, podejmowane przez dotknięte kryzysem państwa UE.

Kryzys ekonomiczny wstrząsnął szczególnie państwami narażonymi na szoki globalne, a więc gospodarkami unijnymi z dużym udziałem eksportu i usług o intensywnym kontakcie (contact-intensive services). Zaistniała sytuacja wymusza na rządach konieczność wdrożenia dodatkowych pakietów fiskalnych. W rezultacie wzrost poziomu długu publicznego w latach 2020-2021 jest nieunikniony w przypadku wszystkich państw UE, lecz dla wielu z nich - głównie krajów południowych - stanowi poważne zagrożenie dla stabilności sektora finansów publicznych w przyszłości. Stąd państwa UE w lepszej sytuacji fiskalnej zapewniały bardziej bezpośrednie wsparcie budżetowe w walce ze skutkami kryzysu wywołanego COVID-19, podczas gdy państwa członkowskie w gorszej sytuacji budżetowej - zwłaszcza kraje południowe - w większym stopniu wspierały płynność finansową, a więc stosowały te instrumenty, które nie mają bezpośredniego wpływu na wyniki budżetowe ${ }^{27}$. Potwierdzają to dane IMF zaprezentowane na wykresie 1.

Kolejnym ważnym czynnikiem rzutującym na wielkość pakietów fiskalnych jest niepewność co do długości trwania pandemii i tempa szczepień, która współwystępuje z wysoką niepewnością sektora usług (szczególnie contact-intensive) odnośnie do terminu całkowitego otwarcia gospodarek i zniesienia dystansu społecznego. Dodatkowo towarzyszy jej wysoka niepewność konsumentów, w tym gospodarstw domowych o niskich dochodach, które najsilniej odczuły skutki kryzysu zdrowotnego i ekonomicznego. Niepewność - niezależnie od tzw. przestrzeni fiskalnej i istniejących ograniczeń budżetowych - skłania rządzących do podejmowania interwencji fiskalnej.

Na wykresie 4 przedstawiono zależność między poziomem niepewności mierzonej Światowym Wskaźnikiem Niepewności Pandemicznej (World Pandemic Uncertainty Index, WPUI) ${ }^{28}$

26 S. Haroutunian, S. Osterloh, K. Sławińska, The Initial Fiscal Policy Responses of Euro Area Countries to the COVID-19 Crisis, "Economic Bulletin” 2021, nr 1, s. 82.

27 Communication..., s. 2.

28 Indeks WPUI jest konstruowany przez zliczenie, ile razy słowo "niepewność" występuje w pobliżu słowa związanego z pandemią w raportach krajowych Economist Intelligence Unit (EIU). Indeks jest procentem słowa 


\section{Wykres 4. Światowy Wskaźnik Niepewności Pandemicznej (WPUI) a Indeks Wsparcia Ekono- micznego (ESI) w wybranych państwach UE (I i II kw. 2020 r.)}

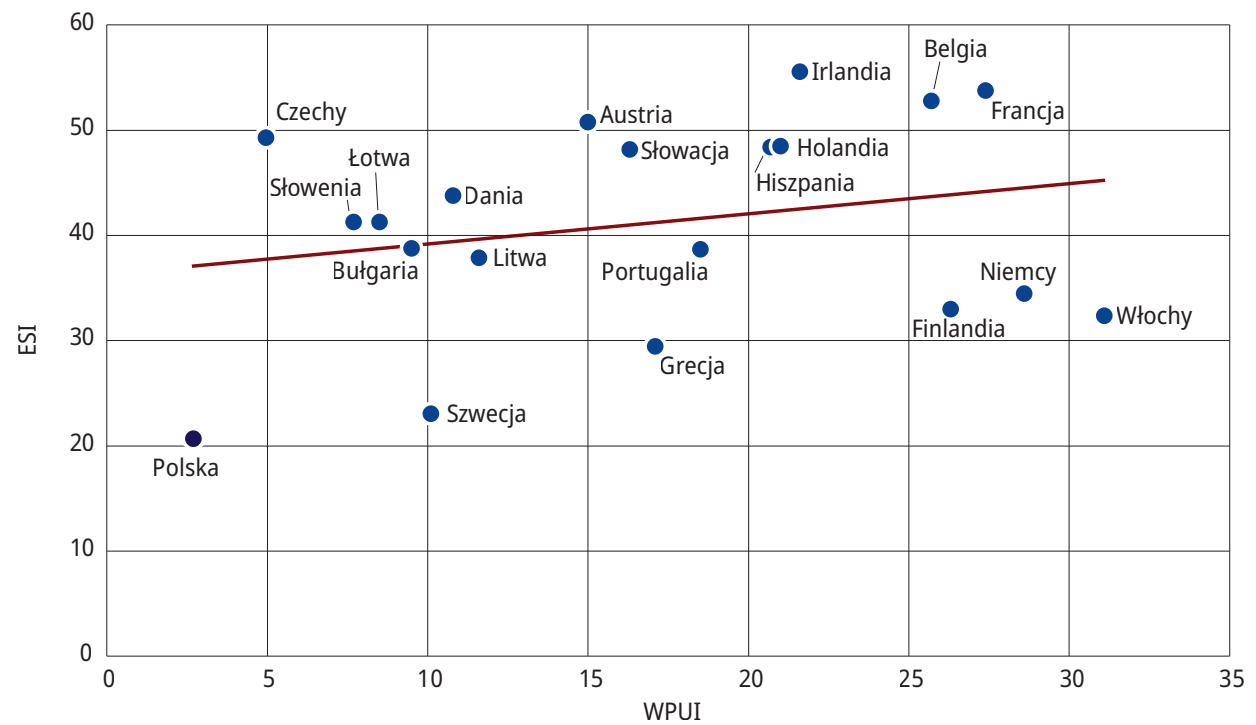

Źródło: opracowanie własne na podstawie danych T. Hale et al., A Global Panel Database of Pandemic Policies (Oxford COVID-19 Government Response Tracker), "Nature Human Behaviour" 2021, https://doi.org/10.1038/ s41562-021-01079-8 oraz World Pandemic Uncertainty Index (WPUI), https://worlduncertaintyindex.com/data/ [dostęp: 18 sierpnia 2021 r.].

a Indeksem Wsparcia Ekonomicznego (Economic Support Index, ESI) w okresie dwóch pierwszych kwartałów 2020 r. Rządowe wsparcie - uwzględnione w indeksie ESI - obejmowało m.in. dofinansowanie wynagrodzeń i transferów pieniężnych skierowanych do osób, które straciły pracę lub z powodu pandemii nie mogą jej podejmować, a także umorzenie lub przesunięcie w czasie spłaty części długów przez gospodarstwa domowe. Wyższe wartości indeksu ESI oznaczają, że dane państwo rekompensuje wyższy procent utraconych zarobków i/lub zapewnia większą ulgę w zadłużeniu, a tym samym próbuje przeciwdziałać negatywnym skutkom gospodarczym COVID-19 dla osób fizycznych. Przy tym wskaźniki te nie mierzą skuteczności reakcji rządzących, lecz są raczej syntetycznymi miarami intensywności polityki rządu²9.

Na podstawie danych przedstawionych na wykresie 4 nie można jednoznacznie stwierdzić, że im wyższy poziom niepewności, tym silniejsza reakcja ze strony rządów mająca na celu podtrzymanie spadku dochodów gospodarstw domowych w pierwszych dwóch kwartałach

„niepewny” i jego wariantów, które pojawiają się w pobliżu terminów określających pandemię w raportach krajowych EIU, pomnożonym przez 1000. Wyższa liczba oznacza większą niepewność związaną z pandemią, niższa zaś - mniejszą niepewność.

29 T. Hale et al., A Global Panel Database of Pandemic Policies (Oxford COVID-19 Government Response Tracker), „Nature Human Behaviour" 2021, https://doi.org/10.1038/s41562-021-01079-8. 
2020 r. Zależność taką zauważono jedynie w przypadku Francji, Belgii, Holandii, Hiszpanii i Irlandii. Niski poziom niepewności związany z pandemią COVID-19 występował wraz z niską wartością Indeksu Ekonomicznego Wsparcia (ESI) zarówno w Polsce, jak i w Szwecji. Niezależnie od tego siła reakcji fiskalnej rządu zależała przede wszystkim od etapu pandemii COVID-19, w jakim znajdowała się gospodarka, a - jak wiadomo - przebieg epidemii nie był wszędzie jednakowy.

\section{Podsumowanie}

Jednym z problemów rządzących w dobie pandemii koronawirusa jest wybór właściwego kierunku polityki fiskalnej, która pozwoli zminimalizować ekonomiczne skutki kryzysu i przywrócić stabilizację makroekonomiczną przy relatywnie niskich kosztach fiskalnych.

Z przeglądu literatury przedmiotu wynika, że polityka fiskalna powinna odgrywać kluczową rolę w przywróceniu stabilności gospodarki unijnej dotkniętej kryzysem zdrowotnym i ekonomicznym. Argumentem za zastosowaniem keynesowskich metod pobudzania koniunktury są spotęgowane efekty mnożnikowe, jakie można uzyskać dzięki ekspansywnej polityce fiskalnej w czasie kryzysu. Niezaprzeczalną przesłankę dla interwencji fiskalnej stanowią też bliskie zera stopy procentowe w państwach UE, w tych warunkach bowiem istnieją ograniczone możliwości prowadzenia ekspansywnej polityki pieniężnej. Gdy uwzględni się te czynniki, za racjonalne należy uznać działania rządów, które udzieliły bezprecedensowo dużej pomocy fiskalnej swoim gospodarkom dotkniętym pandemią koronawirusa.

Niestety, zastosowanie nadzwyczajnych środków powiększyło nierównowagę w finansach publicznych, a poziom długu publicznego rzędu 90\% PKB przekroczyło aż pięć gospodarek unijnych. Z danych IMF wynika, że państwa o większej przestrzeni fiskalnej (Niemcy, Wielka Brytania, USA i Japonia) - cechujące się większą zdolnością do uzyskiwania dochodów - częściej decydowały się na bezpośrednie wsparcie z budżetu walki ze skutkami kryzysu wywołanego COVID-19. Natomiast większość państw UE (głównie kraje śródziemnomorskie) z powodu ograniczeń budżetowych wybierała wspieranie płynności finansowej, a więc wykorzystywanie instrumentów, które nie mają bezpośredniego wpływu na wyniki budżetowe.

Warto pokreślić, że niezależnie od wyników budżetowych państwa UE powinny unikać przedwczesnego wycofywania wsparcia fiskalnego dla swoich gospodarek i dostosowywać pomoc fiskalną do zmieniającej się sytuacji pandemicznej. Jeśli kryzys zdrowotny zostanie przezwyciężony, to doraźne środki wsparcia fiskalnego powinny przekształcić się w bodźce fiskalne stymulujące odporne i trwałe ożywienie. Warunkami skuteczności instrumentów - zgodnie z zasadą 3T w polityce fiskalnej - są ich doraźny charakter, odpowiednie ukierunkowanie, a także stopniowe ich wycofywanie. Komisja Europejska miała to na uwadze i w marcu 2020 r. dopuściła możliwość uruchomienia generalnej klauzuli wyjścia w ramach Paktu Stabilności i Wzrostu. Uznała tym samym za niezbędną pomoc fiskalną ponad limit wydatkowy wynikający z reguł fiskalnych. Jednocześnie akcentuje się, że tylko doraźne i ukierunkowane instrumenty wsparcia fiskalnego nie będą stanowiły trwałego obciążenia dla finansów publicznych i zapewnią neutralność budżetową w perspektywie średnioterminowej. 


\section{Bibliografia}

Afonso A., Expansionary Fiscal Consolidations in Europe. New Evidence, „Working Papers Series” 2006, nr 675.

Alesina A., Perotti R., Fiscal Adjustments in OECD Countries: Composition and Macroeconomic Effects, „IMF Staff Papers" 1997, t. 44, nr 2.

Alesina A., Tabellini G., Bureaucrats or Politicians? Part I: A Single Policy Task, „American Economic Review” 2007, t. $97, \mathrm{nr} 1$.

Alesina A., Tabellini G., A Positive Theory of Fiscal Deficits and Government Debt, "The Review of Economic Studies” 1990, t. 57, nr 3, https://doi.org/10.2307/2298021.

Alesina A., Tabellini G., Why Is Fiscal Policy Often Procyclical, „NBER Working Paper Series” 2005, nr 11600.

Alt J.E., Lassen D.D., Fiscal Transparency, Political Parties, and Debt in OECD Countries, „European Economic Review” 2006, t. 50, nr 6, https://doi.org/10.1016/j.euroecorev.2005.04.001.

Auerbach A.J., Gorodnichenko Y., Measuring the Output Responses to Fiscal Policy, „American Economic Journal: Economic Policy" 2012, t. 4, nr 2, https://doi.org/10.1257/pol.4.2.1.

Auerbach A.J., Gorodnichenko Y., Output Spillovers from Fiscal Policy, „American Economic Review” 2013, t. 103, nr 3, https://doi.org/10.1257/aer.103.3.141.

Beetsma R.M.W.J., Debrun X., Fiscal Councils: Rationale and Effectiveness, „IMF Working Papers” 2016, t. 16, nr 86. Beetsma R.M.W.J. et al., Independent Fiscal Councils: Recent Trends and Performance , IMF Working Papers” 2018, t. 18 , $\operatorname{nr} 68$.

Birol Ö.H., Gencer A.H., The Keynesian System: Fiscal and Monetary Policy Guidelines, „GSTF International Journal of Business Review" 2014, t. 3, nr 3.

Bose S., Bhanumurthy N.R., Fiscal Multipliers for India, http://www.nipfp.org.in/media/medialibrary/2013/09/ WP_2013_125.pdf.

Calmfors L., Wren-Lewis S., What Should Fiscal Councils Do?, „Economic Policy” 2011, t. 26, nr 68.

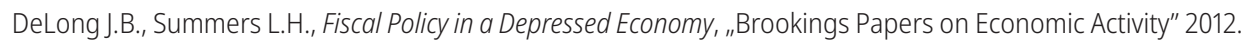

Fatás A., Summers L.H., The Permanent Effects of Fiscal Consolidation, „NBER Working Paper” 2016, nr 22374.

Friedman M., Heller W., Monetary vs. Fiscal Policy, W.W. Norton \& Company, New York 1969.

Hagemann R., How Can Fiscal Councils Strengthen. Fiscal Performance?, „OECD Journal: Economic Studies” 2011, nr 1. Hagen J. von, Harden I., Budget Processes and Commitment to Fiscal Discipline, "European Economic Review” 1995, t. 39, nr 3-4.

Hale T. et al. , A Global Panel Database of Pandemic Policies (Oxford COVID-19 Government Response Tracker), „Nature Human Behaviour" 2021, https://doi.org/10.1038/s41562-021-01079-8.

Haroutunian S., Osterloh S., Sławińska K., The Initial Fiscal Policy Responses of Euro Area Countries to the COVID-19 Crisis, „Economic Bulletin” 2021, nr 1.

Herda J., Pomiar mnożnika fiskalnego, „Studia i Prace WNEIZ US” 2017, nr 47/1, https://doi.org/10.18276/ sip.2017.47/1-03.

Herndorn T., Ash M., Pollin R., Does High Public Debt Consistently Stifle Economic Growth? A Critique of Reinhart and Rogoff, „Cambridge Journal of Economics” 2014, t. 38, nr 2, https://doi.org/10.1093/cje/bet075.

Keynes J.M., Ogólna teoria zatrudnienia, procentu i pieniqdza, Wydawnictwo Naukowe PWN, Warszawa 2003.

Krugman P.R., St. Augustine and Secular Stagnation, https://krugman.blogs.nytimes.com/2015/03/16/st-augustine-and-secular-stagnation/. 
Perotti R., Kontopoulos Y., Fragmented Fiscal Policy, „JJournal of Public Economics" 2002, t. 86, nr 2.

Reinhart C.M., Rogoff K.S., Growth in a Time of Debt, „NBER Working Paper Series” 2010, nr 15639.

Scott J.M. et al., The Impact of COVID-19 on the Internal Market, Policy Department for Economic, Scientific and Quality of Life Policies, European Parliament, Luxembourg 2021.

Steel I., Harris T., COVID-19 Economic Recovery: Fiscal Stimulus Choices for Lower-Income Countries, Institute for Fiscal Studies, London 2020.

Wren-Lewis S., Aggregate Fiscal Policy under the Labour Government. 1997-2010, „Oxford Review of Economic Policy" 2013, t. 29, nr 1, s. 25-46, https://doi.org/10.1093/oxrep/grt012.

\section{Raporty, dokumenty}

European Commission, Communication from the Commission to the European Parliament, the Council, and the European Central Bank on the 2021 Draft Budgetary Plans: Overall Assessment, Brussels 2020.

European Commission, Report on Public Finances in EMU , „Institutional Paper” 2021, nr 147.

Eurostat, General Government Gross Debt (EDP Concept), Consolidated - Annual Data, https://ec.europa.eu/eurostat/tgm/table.do?tab=table\&init=1\&language=en\&pcode=tipsgo10\&plugin=1.

Eurostat Database, Real GDP Growth Rates - volume [TEC00115], https://ec.europa.eu/eurostat/databrowser/ view/tec00115/default/table?lang=en.

International Monetary Fund, Fiscal Monitor Database of Country Fiscal Measures in Response to the COVID-19 Pandemic, 2021, https://www.imf.org/en/Topics/imf-and-covid19/Fiscal-Policies-Database-in-Response-to-COVID-19.

OECD, Country Tax Measures During the COVID-19 Pandemic, https://www.oecd.org/tax/tax-policy/.

OECD, Tax and Fiscal Policy in Response to the Coronavirus Crisis: Strengthening Confidence and Resilience, Paris 2020.

OECD, Tax Policy Reforms 2021: Special Edition on Tax Policy during the COVID-19 Pandemic, 2021, https://doi. org/10.1787/427d2616-en.

World Pandemic Uncertainty Index (WPUI), https://worlduncertaintyindex.com/data/. 